\title{
Human in the world of culture: the great patriotic war in the historical and cultural heritage of northeast of Russia (on the example of Yakutia)
}

\author{
Saassylana Sivtseva*, Olga Parfenova \\ Northeastern Federal University, 677000, Yakutsk, Russia,
}

\begin{abstract}
The historical and cultural heritage, expressed in monuments, architectural structures, dedicated to the Great Patriotic War, today is significant. The purpose of the article is to determine the role of society in perpetuating the memory of the Great Patriotic War. The authors conclude that the events of World War II find a lively response from the public. At the same time, new tendencies in commemorative practices are traced tragic pages of history that until recently were "uncomfortable" (and in Soviet times banned for research), such as human losses, extremely high mortality of the civilian population from hunger, forcibly transferred to special settlements, - began to be reflected in the construction of monuments, memorable places. The location of these monuments is specific - they were erected at a certain distance from public places, at the territories of churches (victims of famine, victims of political repressions), which is associated with the predicted ambiguity of their perception.
\end{abstract}

\section{Man in the world of culture. Issues of commotion}

Today there are many definitions of the "culture" concept. Kroeber and Klakhon in 1952 counted 164 different definitions, and even more have appeared since the publication of their review. According to one version, culture is information whose carrier is a social group. Y.M. Lotman defined culture as the totality of all non-hereditary information, methods of its organization and storage (Lotman, 1970, 1976). Today we are talking not only about the possibility of creating, accumulating and transmitting diverse information non-genetically to other individuals and descendants, which fundamentally distinguishes a person from his wild relatives, but also about the social stage of evolution, characterized by a special supra-individual extra-organic system of accumulating, storing and transmitting information from generation to generation, which is important for the collective association of individuals entering the society (Colin, Ursul, 2015). In this context, material cultural objects, historical and cultural heritage, in particular, monuments, architectural structures, in general, places of memory, are responsible not only for the development and

\footnotetext{
*Corresponding author: sivlana@list.ru
} 
preservation of society, but also are a kind of marker that allows us to judge the state of society.

In this regard, it seems relevant to address the problems of commemoration, the preservation of historical, cultural memory. Today, this problem has been actively developed by researchers. And, undoubtedly, this problem belongs to the category of philosophical problems. Commemoration is the memory preservation for significant events of the past in the public mind. Commemoration arises in the present from the desire of the community that exists at the moment to reaffirm the sense of unity and community, strengthening ties within the community through a shared attitude to representing past events. Commemorative practices suggest a set of ways in which the memory of the past is fixed, preserved and transmitted in society (Megill, 2007, 2008; Mazur, 2015, etc.).

For the first time, the questions of the memory existence in society, its structure, and history itself as a science were raised by the French sociologist Maurice Halbwax, then P. Nora, J. Assman, P. Ricoeur, and YM. Lotman, L.P. Repin, L.N. Mazur, S. Bernstein (Halbwax, 2005, 2007; Nora, 1989; Assmann, 2011; Ricker, 2004; Lotman, 1976, 1992; Repina, 2003, 2016; Mazur, 2015; Bernstein, 2016) were engaged in research of this area. Recently, new trends in the study of memory problems related to the media and blogosphere have appeared (Hoskins, 2009; Schwarz, 2014; Trubina, 2010, 2018; Van Dijck, 2007; Youngblood, 2007; Macdonald, 2013). There are also reserachs devoted to the problem of historical, cultural memory in Russia (Carleton, 2011; Brandenberger, 2002; Etkind, 2012; Wood, 2011; Rutten, Fedor, Zvereva, 2013; Tumarkin, 2003; Oushakine, 2007).

Methodological issues were developed by A. Confino, S. Ginzburg, Anne John, D. Barthel-Bachier, Le Goff, J., L.P. Repin, L.N. Mazur et al. (Confino, 1997; BarthelBouchier, 2015; Chartier, 2015; Repina, 2003, 2016; Mazur, 2013, 2015, etc.).

The works of Russian historians V.V. Korneeva, E.F. Krinko, V.M. Kulisha et al. were dedicated to this topic. The key problems of Russian historical science remain its further theoretical improvement of research in the field of military history; recreation based on a scientific analysis of an objective, historically truthful picture of the causes, course and results of the war; revealing the sources and patterns of Soviet people victory in the Great Patriotic War.

Today, scientists who develop memory problems have come to the conclusion that by manipulating images of the past, one can influence the memory development of the past necessary for the present. In this regard, researchers come to the conclusion that memory manipulation is latent violence, and it is associated with the activities of the state. However, we note that this phenomenon is a necessary function of the state, without this kind of "manipulation" the existence of such a complex organism as a state is impossible (if it wants to be preserved as such).

Today, in Russia, historical memory is preserved and increased not only by the state the influence of the public on its development is also growing today. And this is expressed in the organization of public works on the creation of new monuments and memorials with the involvement of non-state funds. The situation that has developed in recent years in the Yakut Republic is proof of this.

The memory of the Great Patriotic War, undoubtedly, is an event cementing multinational Russian society. The purpose of the article is to determine the role of society in perpetuating the memory of the Great Patriotic War. In accordance with this goal, the authors attempt to study the state of historical and cultural heritage at the North-East of Russia - Yakutia, and specifically - monuments, architectural structures dedicated to the Great Patriotic War, the history of their construction.

\section{Research methods}


During research development, the authors were guided by the principles of an integrated approach for the study problem. The methods of observation, comparison, description, formalization, historical-comparative, historical-genetic, problem-chronological, synthesis and analysis, induction, deduction were used.

\section{World War II: historical and cultural heritage of Yakutia}

The list of memorial sites dedicated to the Great Patriotic War in the city of Yakutsk until recently was very small. This is Victory Square, which was built in 1970 on the occasion of the 25th Victory anniversary in the Great Patriotic War. It was from here that during the war years tens of thousands of Yakutians went to the front. And on the occasion of the 30th anniversary of the victory in 1975, the Victory memorial complex dedicated to the Yakut warriors and participants of the Great Patriotic War was opened on this square. These structures were built by decision of the state bodies of the Yakut ASSR.

In recent years, the old monuments on Victory Square have been updated, new memorial places have been appeared in the city dedicated to the events of the Great Patriotic War, and at the same time, a new "reading" of the tragic pages of Yakutia history has appeared. Due to the limited scope of the article, we will dwell in more detail on modern monuments and structures that reinterpret the events of 1941-1945.

In 1992, a memorial was erected at the Yakutsk airport in honor of the 50th anniversary of the Alaska-Siberia airway opening. In 2012, Mother's Square was opened on Saysary Lake shore - as a tribute to mothers who lost their sons during the war. On the day of World War II end on September 2, 2015, the Victory memorial complex (on Victory Square) was supplemented by the construction of the Tuymaada Soldier (counting of those called to the front continues and the memorial is replenished with new names). Monuments were erected to the Heroes of the Soviet Union.

In 2015, a monument to workers was unveiled on the territory of St. Nicholas Church, victims of the workers in the rear - in the form of a millstone (moloch) - a stone circle. Great support in its construction was provided by the People's Deputy of the Republic of Sakha (Yakutia), general director of the diamond mining company "Almazy Anabara" M.N. Evseev, deputy Director of the Research Institute of Olonkho, Northeast Federal University named after A.V. Migalkin, sculptor V.Y. Sivtsev. At the grand opening, it was noted that the monument will serve as the beginning of a great work to preserve the names of tens thousands Yakutians who sacrificed their lives in the rear for the name of the great Victory. "We walked for a long time to this monument. And the place of establishment is not accidental. St. Nicholas Church is one of the first churches in the city of Yakutsk. This monument here will remind again and again for parishioners about the feat of the Yakut people and encourage us to pray so that we do not forget about their heroism every day", said Bishop Yakutsky and Roman Lensky (https://sakhapress.ru/ archives / 202442. Date of access 06.15.2019).

Losses in the rear were significant, mortality from starvation, and malnutrition was extremely high. Mortality rates in Yakutia were 1.9 times higher than in Siberia, 1.8 times higher than in the Urals, and 1.8 times higher than in the RSFSR (according to incomplete data). (Isupov, Kornilov, 2017; Sivtseva, 2016).

During the war, Yakutia accepted over 3 thousand Lithuanians for special settlement, for many of them it turned out to be the last refuge: most exiles, representatives of Lithuanian nationality, died here from cold, hunger and disease. These are children, old people and women, the names of many of them can no longer be recognized. (Knudsen, 2011; Davoliute, 2005).

The compatriots could not immediately erect a monument to the victims of political repression from Lithuania, although they wanted to install it since 2002. It was possible to 
resolve all administrative obstacles only by 2011, on the anniversary of the 70th anniversary of the mass deportation of Lithuanians. The monument in the form of a memorial plaque stands on the territory of the Catholic Church in the city of Yakutsk with the blessing of Bishop Kirill Klimovich (ordinar of the Roman Catholic Diocese in Irkutsk). This was made possible thanks to the activities of Gintaras, a public organization (Lithuanian community), created in 1996 by the descendants of repressed Lithuanians who linked their fate with Yakutia. At the opening of the monument came the descendants of the exiles, representatives of the republic national communities, journalists and ordinary citizens (http://www.1sn.ru/48533.html. Date of appeal 06/15/2019).

The erected bust of I.V. Stalin - a monument whose significance must be described separately. This is a bronze bust 2.5 meters high on a pedestal with the inscription "I.V. Stalin". It was also erected not at public expense, was ordered by the top-management of "Almazy Anabara" enterprise and delivered to the enterprise. It was inaugurated on Victory Day on May 8, 2013. The opening ceremony, according to News.Ykt.Ru, was attended by about 100 people, mostly of advanced age. Among them there were the Secretary of the Central Committee of the Communist Party, State Duma deputy Kazbek Taysaev, the general director of "Almazy Anabara" Matvey Evseev, the head of the local branch of the Communist Party Viktor Gubarev and war veteran Georgy Aprosimov.

Communists initially, in 2007, wanted to erect a monument to Stalin in the middle of the Veteran's Square (the Victory memorial complex on Victory Square), but Yuri Zabolev, then the head of the city of Yakutsk, spoke out against this initiative. He stated that he did not consider Stalin worthy of this. After that, the Yakut Communists tried several times to find a place for the monument, until general director of "Almazy Anabara" M. Evseev agreed to erect Stalin's bust on the enterprise territory.

It is known that setting the monument was sharply criticized by local human rights activists, who regarded this step as unacceptable and inadmissible. However, we note that supporters of the Stalin's monument installation were in a greater number. The new bust became the third monument to Stalin in Yakutia, been installed recently. In 2005, the bust appeared on the initiative of the city council of war veterans on Victory Square in the city of Mirny (Republic of Sakha (Yakutia)), and in 2009 - in the village of Amga (Republic of Sakha (Yakutia)), also on the initiative of war veterans (https: / /lenta.ru/news/2013/05/08/stalin/. Date of access 12.05.2019).

There are not quite typical monuments in the Yakut villages. For example, in the Megino-Kangalassky ulus of the Republic of Sakha (Yakutia), a bust to I.M. Nakhodkin was included in the military glory complex, chairman of the collective farms named after Molotov and the "Commune of Suol" (trans. "Path to the commune"). The grateful fellow countrymen erected a monument to him on the occasion of the 50th anniversary of the Great Victory, paying off his debt to his civil feat - he saved many people from starvation, at his own peril and risk, feeding the starving collective farmers in all the possible and impossible ways. And there were many of those leaders who paid a terrible tribute of prison and death for this.

\section{Conclusion}

A study of the historical and cultural heritage of Yakutia dedicated to the Great Patriotic War revealed new trends in commemorative practices.

Modern monuments and memorials are no longer impersonal. On Victory Square, the Victory memorial complex was supplemented by the construction of the Tuymaada Soldier (the names of 20563 people engraved in gold on the stella of the complex were called up by the Yakutsk city military enlistment office from 1941 to 1945; the count of those called to the front continues and the memorial is replenished with new names). Monuments and 
busts for the heroes of the Soviet Union F.K. Popov, K.K. Krasnoyarov, the chairman of the collective farm I.M. Nakhodkin and others were erected. In the republic's uluses, work is under way to restore the lists of those mobilized who died on the fronts of the Great Patriotic War, as well as lists of workers who died in the rear.

The tragic pages of history, which until recently were "uncomfortable" (and forbidden for research in the Soviet times), such as human losses, extremely high mortality of the civilian population from hunger, forcibly moved to special settlements, are reflected in the construction of monuments and memorial sites. Public nostalgia for the Soviet state was expressed in the construction of I. Stalin monument. The location of these monuments is specific - they were erected at a certain distance from public places, at the territories of churches (the Nikolskaya Church - to the victims of hunger, the Catholic Church - to the victims of political repression - deported Lithuanians) at the territories of enterprises (I. Stalin), which is associated with their predicted ambiguity public perceptions.

\section{References}

1. J. Assmann, Cultural Memory and Early Civilization: Writing, Remembrance, and Political Imagination1 January, (2011). DOI: 10.1017/CBO9780511996306

2. D. Barthel-Bouchier, Cultural heritage: Tangible and intangible markers of collective memory, Routledge International Handbook of Memory Studies, 221-232 (2015). DOI: $10.4324 / 9780203762844$.

3. S. Bernstein, Remembering war, remaining Soviet: Digital commemoration of World War II in Putin's Russia, Memory Studies, 9 (4), $422-436$ (2016). DOI: $10.1177 / 1750698015605573$.

4. D. Brandenberger, S. Belyakov, National Bolshevism: Stalinist Mass Culture and the Formation of Modern Russian National Identity, 1931-1956, Novyi mir, 10, 194-199 (2002). WOS:000285733200045.

5. G. Carleton, History done right: War and the dynamics of Triumphalism in Contemporary Russian culture, Slavic Review, 70 (3), 615-636 (2011). WOS:000295743000006

6. R. Chartier, International Encyclopedia of the Social \& Behavioral Sciences: Second Edition, Cultural History, 420-425 (2015). DOI: 10.1016/B978-0-08-097086-8.62108-6

7. A. Confino, Collective memory and cultural history: Problems of method, American Historical Review, 102 (5), 1386-1402 (1997). DOI: 10.2307/2171069

8. V. Davoliute, Deportee memoirs and Lithuanian history: The double testimony of Dalia Grinkevičiūté, Journal of Baltic Studies, 36, (1), 51-68 (2005). WOS:000227683400004

9. A. Etkind, Mourning and Melancholia in Putin's Russia: an essay in qualitative mnemonics, East European Memory Studies, 9, 1-10 (2012).

10. A. Hoskins, The mediatisation of memory, Save As... Digital Memories, 27-43 (2009). DOI book: 10.1057/9780230239418.

11. V.A. Isupov, G.E. Kornilov, Population of Russia during the World War II (19391945), Ural'skij Istoriceskij Vestnik, 57 (4), 46-53 (2017).

12. M. Khalbvaks, Collective and historical memory, Reserve stock, 2, 8 - 27 (2005). 
13. M. Khalbvaks, Social frameworks of memory, Transl. from fr. and intr. article S.N. Zenkin (New publishing house, Moscow, 2007).

14. B.T. Knudsen, Deportation day: Live history lesson (Conference Paper), Museum International Volume, 63 (1-2), 109-118 (2011).

15. K.K. Kolin, A.D. Ursul, Information and culture. Introduction to informational culturology (Publishing house «Strategic priorities», Moscow, 2015).

16. V.V. Korneev, The Far East of USSR during The Great Patriotic War in modern Russian historiography (1991-2010), The Far East problems., 3, 117-122 (2011).

17. E.F. Krinko, Modern Russian historiography of the Great Patriotic War: results of the couple of decades, Old times, 4 (14), 6-21 (2009).

18. V.M. Kulish, Soviet historiography of the Great Patriotic War. Soviet historiography (RSUH, Moscow, 1996).

19. Yu. M. Lotman, Articles on cultural typology, Materials for literary theory course. Tartu, 1, 5-6 (1970).

20. Yu. M. Lotman, On The Reduction and Unfolding of Sign Systems (The Problem of "Freudianism and Semiotic Culturology"), Soviet Studies in Literature, 12 (2), 44-52 (1976). DOI: 10.2753/RSL1061-1975120244

21. Yu. M. Lotman, Articles on semiotics and cultural topology (In 3 volumes, Tallin, 1992).

22. L.N. Mazur, The image of the past: historical memory forming, News of Ural federal university, 2 (3) (117), 243-256 (2013).

23. L. Mazur, The visualization of history: A new turn in the development of historical cognition(Review), Quaestio Rossica, 3 (3), 160-178 (2015). DOI: $10.15826 /$ qr.2015.3.117

24. S. Macdonald, Memorylands: Heritage and identity in Europe today, Memorylands: Heritage and Identity in Europe Today, (2013). DOI: 10.4324/9780203553336

25. A. Megill, Historical epistemology (Kanon+; RSDP «Rehabilitation, Moscow, 2007).

26. A. Megill, Historical representation, identity, allegiance, Narrating the Nation: Representations in History, Media and the Arts, 11, 19-34 (2008). http://orcid.org/00000003-0159-9273.

27. P. Nora, Between Memory and History: Les Lieux de Mémoire, Representations, 26, 724 (1989). DOI: 10.2307/2928520.

28. Oushakine, S. Alex, "We're nostalgic but we're not crazy": Retrofitting the past in Russia, Russian Review, 66 (3), 451-482 (2007). DOI: 10.1111/j.14679434.2007.00453.x

29. L.P. Repina, Cultural memory and problems of historical description (historiographical notes) (SD HSE, Moscow, 2003).

30. L. Repina, Historical Memory and National Identity: Approaches and Research Methods, Dialog so vremenem-Dialogue with time, 54, 9-15 (2016).

31. P. Riker, Memory, history, silence (2004). 
32. E. Rutten, J. Fedor, V. Zvereva, Memory, conflict and new media: Web wars in postsocialist states, Memory, Conflict and New Media: Web wars in post-socialist states, (2013). DOI: 10.4324/9780203083635

33. O. Schwarz, The past next door: Neighbourly relations with digital memory-artefacts, Memory Studies, 7 (1), 7-21 (2014). DOI: 10.1177/1750698013490591

34. S. Sivtseva, On methods and results of the research of the historical demography problems (evidence from the Republic of Sakha (Yakutia), Russia, 1939-1959). 3rd International Multidisciplinary Scientific Conference on Social Sciences and Arts, SGEM 2016, Albena, Bulgaria (2016). WOS:000395727400060

35. E. Trubina, Past wars in the Russian blogosphere: on the emergence of cosmopolitan memory, Digital Icons: Studies in Russian, Eurasian and Central European New Media, 4, 63-85 (2010).

36. E.G. Trubina, Philosophy in anthropology: Learning concepts from life, Etnograficeskoe Obozrenie, 5, 59-77 (2018). DOI: 10.31857/S086954150001477-4.

37. N. Tumarkin, The Great Patriotic War as myth and memory, European Review, 11 (4), 595-611 (2003). DOI: 10.1017/S1062798703000504

38. J. Van Dijck, Mediated Memories in the Digital Age (Stanford University Press, Palo Alto, CA, 2007).

39. E.A. Wood, Performing memory: Vladimir Putin and the celebration of World War II in Russia, Soviet and Post Soviet Review, 38 (2), 172-200 (2011). DOI: 10.1163/187633211X591175

40. D. Youngblood, Russian War Films: On the Cinema Front, 1914-2005 (University of Kansas Press, Lawrence, MA, 2007).

41. Information on https://sakhapress.ru/archives/202442.

42. Information on http://www.1 sn.ru/48533.html.

43. Information on https://lenta.ru/news/2013/05/08/stalin/. 